\title{
Unpredictability of Gradients during Preservation Phase of the Linear Constructions
}

\author{
Moein Zargar ${ }^{1}$, Hossein Gholami ${ }^{2}$, Hossein Norouzi ${ }^{3}$, Morteza Soltani ${ }^{4}$, Shahide Dehghan ${ }^{5}$, \\ Vijay P. Singh ${ }^{6}$, Mohsen Ghane ${ }^{7 *}$, Kaveh Ostad-Ali-Askari ${ }^{2}$ \\ ${ }^{I}$ Department of Civil Engineering, Farzanegan Institute of Higher Education, Isfahan, Iran \\ ${ }^{2}$ Department of Civil Engineering, Isfahan (Khorasgan) Branch, Islamic Azad University, Isfahan, Iran \\ ${ }^{3}$ Department of Civil Engineering, Maybod Branch, Islamic Azad University, Maybod, Yazd, Iran \\ ${ }^{4}$ Department of Architectural Engineering, Shahinshahr Branch, Islamic Azad University, Shahinshahr, Iran \\ ${ }^{5}$ Department of Geography, Najafabad Branch, Islamic Azad University, Najafabad, Iran \\ ${ }^{6}$ Department of Biological and Agricultural Engineering \& Zachry Department of Civil Engineering, Texas A \\ and M University, 321 Scoates Hall, 2117 TAMU, College Station, Texas 77843-2117, U.S.A. \\ ${ }^{7}$ Civil Engineering Department, South Tehran Branch, Islamic Azad University, Tehran, Iran
}

\begin{abstract}
*Corresponding Author: Mohsen Ghane, Civil Engineering Department, South Tehran Branch, Islamic Azad University, Tehran, Iran
\end{abstract}

\begin{abstract}
Instability of the rock and earth slopes in the Andimeshk-Khorramabad Road can cause disastrous events. The road has settled and slipped on an active landslip in the marl and gypsum layers of the Gachsaran Formation, between the Zal Bridge and the Poldokhtar, under the effect of water, lithology and erosion caused by the Seymareh River. The road is threatened by the Rockfall in the north of the Poldokhtar and the Afrineh village, by the rock slide in the northeast of the Tang-e-Malawi and by taluses accumulated on the slopes prone to Creep and Slump between the Tang-e-Malawi and the Afrineh village.
\end{abstract}

Keywords: Rockfall; Afrineh village; Seymareh River; Afrineh village; Zal Bridge

\section{INTRODUCTION}

On the Andimeshk-Khorramabad Road, heavy and repeated rainfalls have caused damages due to instability of the rock and earth slopes, landslide and settlement. This is resulted from the lack of attention to the engineering geology issues in the maintenance phase of the road. Presence of the Seymareh large landslide in the Tang-e-Fani pass and the passage of the road through different geological formations have caused problems in the maintenance phase due to the litho logical changes, tectonic structures, weathering and weather conditions.[5]

\subsection{Slope Failure Mechanism in the Unstable Areas}

Stratigraphic, tectonic and geotechnical characteristics of rocks considering the groundwater conditions intensify the physical and chemical weathering (Ghobadi, 1993), which leads to the formation of areas prone to failure in the aforementioned road. The road has settled and slipped on an active landslip in the marl and gypsum layers of the Gachsaran Formation, between the Zal Bridge and the Poldokhtar in the Pol Tang (Pay Elm) village, under the effect of water, lithology and erosion caused by the Seymareh River that is intensified in the rainy seasons and causes damage. Changes in groundwater level accompanied with swelling of the colored marl and effects of the groundwater leading to dissolution of the gypsum layers along with the erosion of the mentioned landslide heel increases the road settlement every year and increases the movement of the underlying slippery mass. Heavy and repeated rainfalls have increased the pore pressure and decreased the shear strength along the failure surfaces and thus, one of the retaining walls, which has been designed and constructed without drain, has cut and failed along the slippery mass. The other retaining walls and existing drains were not able to stabilize the landslide. The mentioned road crosses several anticlines and synclines and considering the road conditions and the tectonic structure, the rock slopes are unstable. The 
discontinuity systems that are parallel and perpendicular to the axis of the Asmari-Shahbazan limestone anticlines cause rock fall between Poldokhtar and Babazeyd post due to the weathering progress and under the effects of atmospheric precipitation in the rainy seasons, and cause rock slide in the northeast of the Tang-e-Malawi. In 1994, the rock slides in this area were not accompanied with the mortal casualties. The accumulation of materials created by the weathering processes has formed taluses with different thicknesses on the slopes between the Tang-e-Malawi and the Afrine village.[5]

The existence of multiple discontinuous surfaces with decreased shear strength is one of the most important factors causing the slope instability. The presence of numerous discontinuous surfaces, clay soil with high index of plasticity, and increased pore water in rainy months makes the slopes prone to creep and slip (Ghobadi, 1997 and 1994).

In the village of Afrine, the existing one-sided trench in the Aghajari Formation has put the road at the risk of rock fall. Dimensions of the sandstone blocks in the marl layers and Aghajari sandstones are noticeable considering the erosion of marls and the existing fracturing systems in the sandstones and their probable fall on the road will lead to irreparable damage [5]

\section{METHODS AND MATERIALS}

Comprehending of the inclined-work-related risk of falls and expanding novel applied engineering controls for decreasing this risk of falls among craggy working population stays in high demand. Standing on sloped areas prepares a unique circumference for considering the biomechanics and neural qualify of standing. We also inspected the impacts of different dignities of load on these situations. We demonstrate our investigation to show the reactions between slope inconstancy activities and structural consolidation interpositions intended to decrease the difficulty in a zone. At the same time, the slope inconstancy procedures intensively developed, and regressive erosion quickly continued to the landslide threshold.

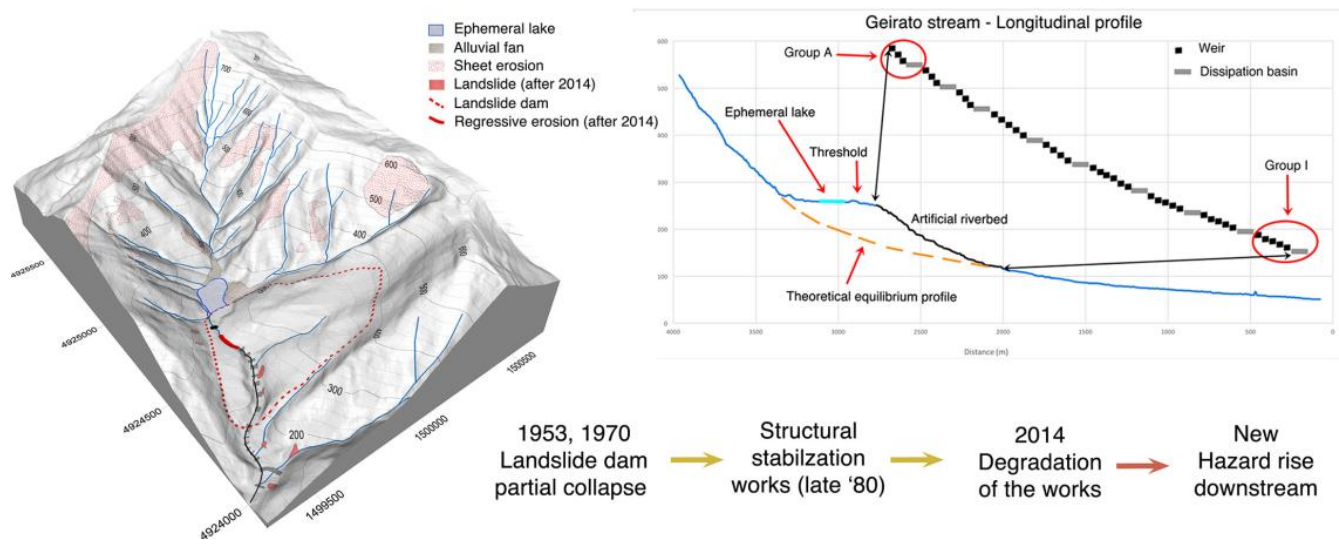

Fig1. Geirato stream - Longitudinal profile [10]

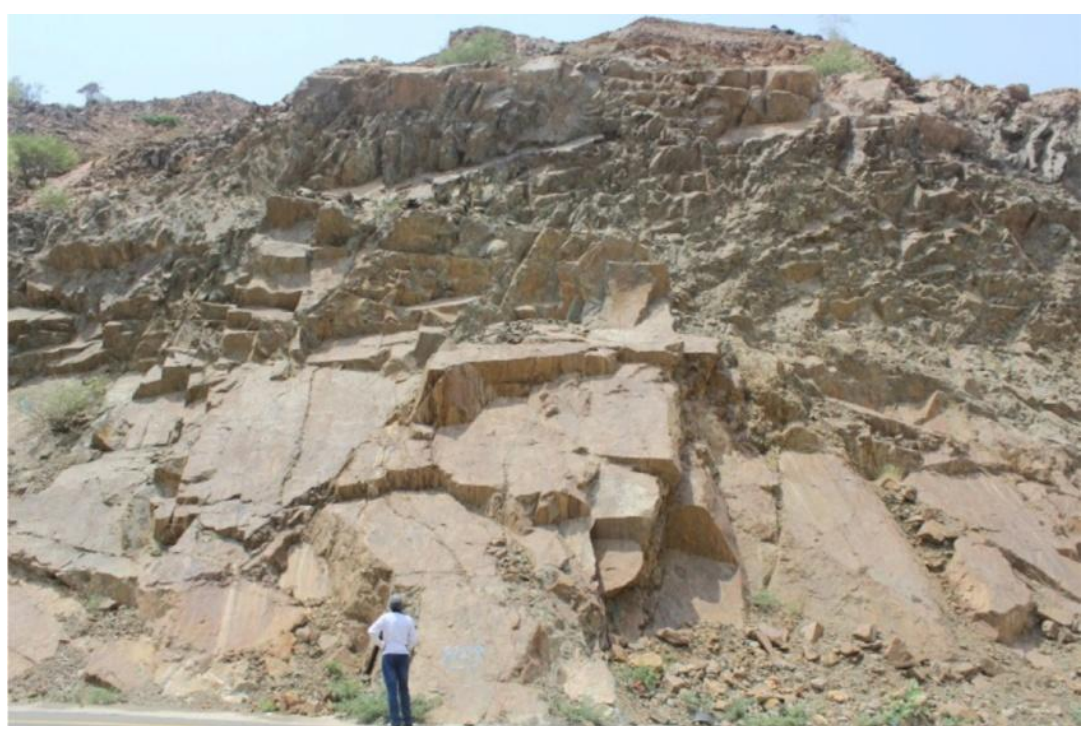

Fig2. Example of structurally controlled failure [26] 


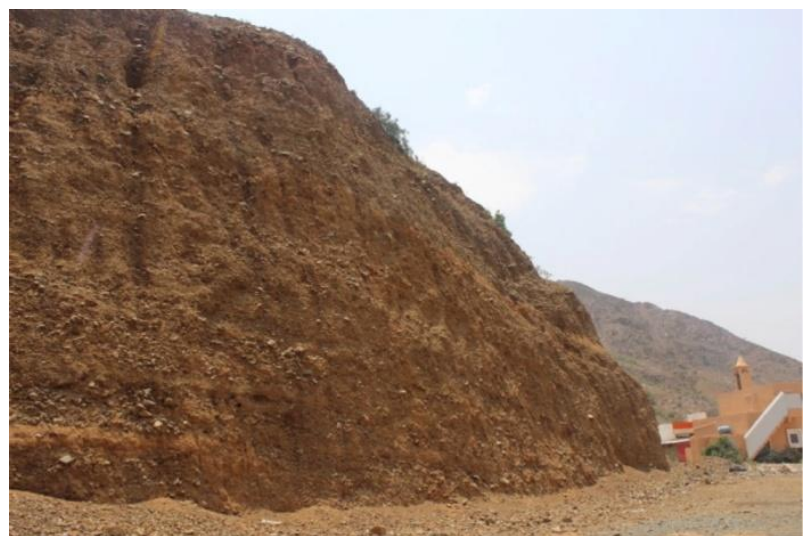

Fig3. Example of non-structurally controlled failure due to highly weathering [26]

Table1. Rock rating system (After Bieniawski, 1989) [26]

\begin{tabular}{|c|c|c|c|c|c|c|}
\hline Row & Parameter & \multicolumn{5}{|c|}{ Range of values } \\
\hline \multirow[t]{3}{*}{1} & $\begin{array}{l}\text { Strength of intact } \\
\text { rock mineral }\end{array}$ & $\begin{array}{c}\text { Point-load } \\
\text { strength index } \\
(\mathrm{MPa})\end{array}$ & $>10$ & 4-10 & $2-4$ & $1-2$ \\
\hline & & UCS (MPa) & $>250$ & $100-250$ & $50-100$ & $25-50$ \\
\hline & Rating & & 15 & 12 & 7 & 4 \\
\hline \multirow[t]{2}{*}{2} & Drill core RQD (\%) & & $90-100$ & $75-90$ & $50-75$ & $25-50$ \\
\hline & Rating & & 20 & 17 & 13 & 8 \\
\hline \multirow[t]{2}{*}{3} & $\begin{array}{c}\text { Spacing of } \\
\text { discontinuities }\end{array}$ & & $>2 \mathrm{~m}$ & $0.6-2 \mathrm{~m}$ & $\begin{array}{c}200-600 \\
\mathrm{~mm}\end{array}$ & $\begin{array}{c}60-200 \\
\mathrm{~mm}\end{array}$ \\
\hline & Rating & & 20 & 15 & 10 & 8 \\
\hline \multirow[t]{5}{*}{4} & $\begin{array}{c}\text { Condition of } \\
\text { discontinuities }\end{array}$ & & $\begin{array}{l}\text { Very rough } \\
\text { surfaces }\end{array}$ & $\begin{array}{l}\text { Slightly } \\
\text { rough } \\
\text { surfaces }\end{array}$ & $\begin{array}{l}\text { Slightly } \\
\text { rough } \\
\text { surfaces }\end{array}$ & $\begin{array}{l}\text { Slickensid } \\
\text { ed } \\
\text { surfaces, } \\
\text { or }\end{array}$ \\
\hline & & & $\begin{array}{c}\text { Not } \\
\text { Continuous }\end{array}$ & $\begin{array}{l}\text { Separation } \\
\quad<1 \mathrm{~mm}\end{array}$ & $\begin{array}{l}\text { Separation } \\
\quad<1 \mathrm{~mm}\end{array}$ & $\begin{array}{l}\text { Gouge }<5 \\
\text { mm thick, } \\
\text { or }\end{array}$ \\
\hline & & & No separation & $\begin{array}{c}\text { Slightly } \\
\text { weathered }\end{array}$ & $\begin{array}{c}\text { Highly } \\
\text { weathered }\end{array}$ & $\begin{array}{c}5 \mathrm{~mm} \\
\text { (continuou } \\
\mathrm{s})\end{array}$ \\
\hline & & & $\begin{array}{l}\text { Unweathered } \\
\text { wall rock }\end{array}$ & Walls & Walls & \\
\hline & Rating & & 30 & 25 & 20 & 10 \\
\hline \multirow[t]{4}{*}{5} & $\begin{array}{l}\text { Groundwater } \\
\text { Rating }\end{array}$ & $\begin{array}{l}\text { Inflow per } 10 \mathrm{~m} \\
\text { tunnel length } \\
(\mathrm{L} / \mathrm{min})\end{array}$ & None & $<10$ & $10-25$ & $25-125$ \\
\hline & & $\begin{array}{c}\text { Ratio of joint } \\
\text { water pressure to } \\
\text { major principal } \\
\text { stress }\end{array}$ & 0 & $<0.1$ & $0.1-0.2$ & $0.2-0.5$ \\
\hline & & General condition & $\begin{array}{l}\text { Completely } \\
\text { dry }\end{array}$ & Damp & Wet & Dripping \\
\hline & Rating & & 15 & 10 & 7 & 4 \\
\hline
\end{tabular}

Table2. Guideline for classification of discontinuity condition in Rock Mass rating [26]

\begin{tabular}{|c|c|c|c|c|c|c|c|c|c|}
\hline $\begin{array}{c}\text { Discontinuity } \\
\text { length } \\
\text { (persistence) }\end{array}$ & \multicolumn{2}{|c|}{$\begin{array}{c}\text { Separation } \\
\text { (aperture) }\end{array}$} & \multicolumn{2}{|c|}{ Roughness } & \multicolumn{2}{c|}{ Infilling (gouge) } & \multicolumn{2}{c|}{ Weathering } \\
\hline $\begin{array}{c}\text { Value } \\
(\mathrm{m})\end{array}$ & Rating & $\begin{array}{c}\text { Value } \\
\text { (mm) }\end{array}$ & Rating & Description & Rating & Description & Rating & Description & Rating \\
\hline$<1$ & 6 & None & 6 & Very rough & 6 & None & 6 & Unweathered & 6 \\
\hline $1-3$ & 4 & $<0.1$ & 5 & Rough & 5 & $\begin{array}{c}\text { Hard } \\
\text { Filling }<5 \\
\text { mm }\end{array}$ & 4 & $\begin{array}{c}\text { Slightly } \\
\text { weathered }\end{array}$ & 5 \\
\hline
\end{tabular}


Unpredictability of Gradients during Preservation Phase of the Linear Constructions

\begin{tabular}{|c|c|c|c|c|c|c|c|c|c|}
\hline $3-10$ & 2 & $\begin{array}{c}0.1- \\
1.0\end{array}$ & 4 & $\begin{array}{c}\text { Slightly } \\
\text { rough }\end{array}$ & 3 & $\begin{array}{c}\text { Hard } \\
\text { Filling }>5 \\
\mathrm{~mm}\end{array}$ & 2 & $\begin{array}{c}\text { Moderately } \\
\text { weathered }\end{array}$ & 3 \\
\hline $10-20$ & 1 & $1-5$ & 1 & Smooth & 1 & $\begin{array}{c}\text { Soft } \\
\text { Filling }<5 \\
\mathrm{~mm}\end{array}$ & 2 & $\begin{array}{c}\text { Highly } \\
\text { weathered }\end{array}$ & 1 \\
\hline$>20$ & 0 & $>5$ & 0 & Slickensided & 0 & $\begin{array}{c}\text { Soft } \\
\text { Filling }>5 \\
\mathrm{~mm}\end{array}$ & 0 & Decomposed & 0 \\
\hline
\end{tabular}

Table3. Guidelines for classification of discontinuity in Rock Mass rating [26]

\begin{tabular}{|c|c|c|}
\hline Rating & Class & Description \\
\hline $100-81$ & I & Very good rock \\
\hline $80-61$ & II & Good rock \\
\hline $60-41$ & III & Fair rock \\
\hline $40-21$ & IV & Poor rock \\
\hline$<20$ & V & Very poor rock \\
\hline
\end{tabular}

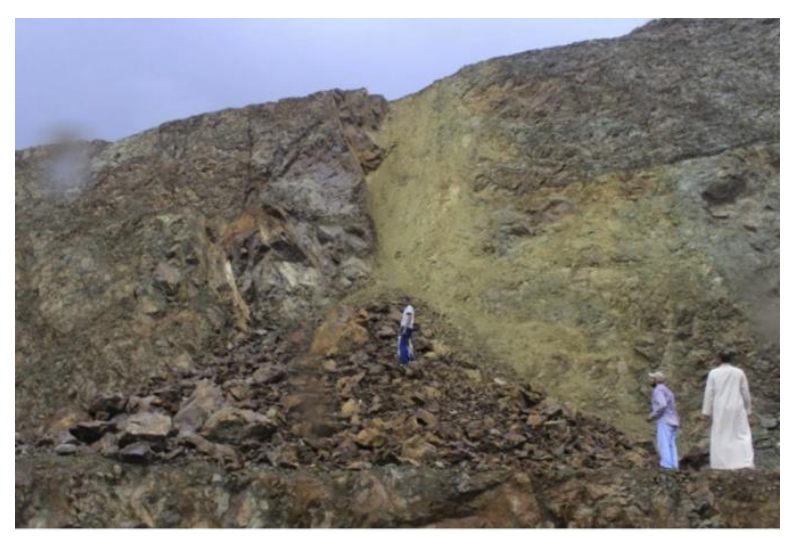

Fig4. Wedge failure at site [26]

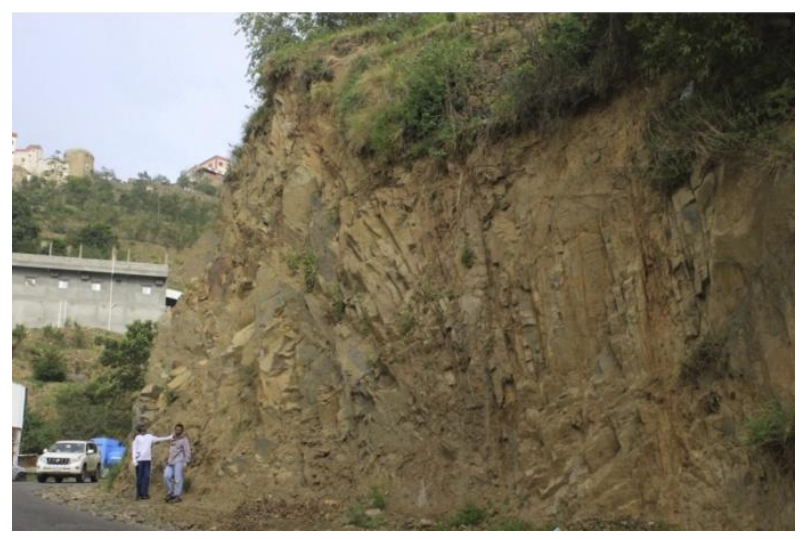

Fig5. Potential for flexural toppling failure [26]

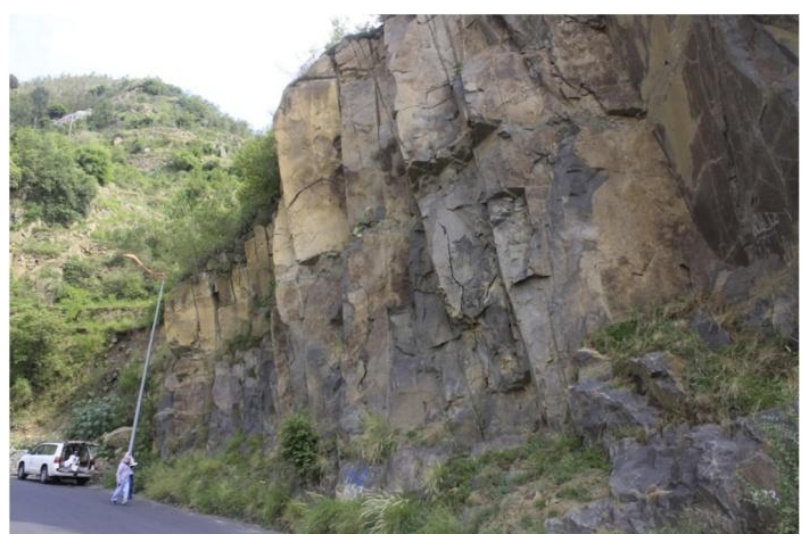

Fig6. Potential for block toppling failure [26] 
The energetic temperament of a bioengineered work sets various outlines the slope design. All these various phases must be taken into the description in the work plan procedure. In this method, we suggest a coincidence of the available procedures and ways of both geotechnical operation and civil engineering plan scheme in order to nearly reverberate the content of bioengineering procedures in the classic geotechnical engineering issues. A planning methodology covering various crucial propose within the lifecycle of a gradient is suggested. Slope inconstancy shows in many shapes, ranging from constant state to punctuated motion, or sophomoric erosion to deep-seated deploying. We can apply a geographic information system (GIS) - depend on the methodology for slope inconstancy evaluations depend on geometrical correlations between topographic slopes and structural interruptions. The method concludes (a) regionalization of point perceptions of directions of structural interruptions in substances so as to produce a digital structural plan, (b) experiment the kinematical probability of special modes of slope fractures by digital elevation model (DEM)- derived slope and aspect data and (c) calculation of consistency scenarios with regard to identified slope fracture methods. The consequences of the education display improved organization of slope inconstancy in the smaller zone with esteem to recognized incidences of deep-rooted rockslides than with respect to narrow translational rockslides, suggesting that organizational control is more significant for deep-rooted rockslides than for narrow translational rockslides. The constancy of rock gradients is measured vital to public protection in roads passing through rock cuts, as well as to people and apparatus security in open pit mines.

\section{RESUlts}

This article evaluates the available slope inconstancy risk evaluation methods. Consequences of the scenario- based investigation display that, in slopes classified to be unbalanced, stress- induced slope variability tends to rise with the cumulative level of water saturation. The investigation shows the expediency of spatially divided information of directions of structural disruptions for medium- to the small- scale grading of slope inconstancy in earth. It displays that both quantitative and qualitative processes have some main detriments with a usual feature being the deficiency of assertion on the geology and geomorphology of gradients. Plus, the task of climatic situations (the most usual landslide triggering component) is important. It is pointed that the available risk evaluation processes depend either on only one classification of results or directly quantify the results of more than one class, which may lead to an under-approximation of the importance of an outcome classification. Finally, the compatibility and validity of the most generally applied results components are considered. The main causative and triggering components responsible for the showing of landslide phenomena, measure their interactions, obtain their weighted coefficients, and compute the inconstancy index, which denotes to the essential possible inconstancy of each natural slope of the considered zone. Large disastrous slope fractures are difficult to anticipate because the underlying instruments triggering slope quickening are hard to study under in-situ situations. For numerical risk evaluation, it is essential to describe the magnitude-frequency dispensation and a temporal model of the landslide regularity. This is often complex for great rock slope catastrophes because of the absence of considerable amounts of large rock slope catastrophes in inventories of a given similar zone or sparse data about the timing.

Rock gradients fail through structurally-controlled mechanisms, worldwide circular catastrophes, or complex instruments depending on structural designs and Rock mass harm. Gradient inconstancy and catastrophes happen because of many reasons such as contrary slope geometries, geological discontinuities, weak or weathered gradient substantial's as well as unadorned weather situations. Exterior weights like heavy precipitation and seismicity could play a important role in gradient catastrophe.

\section{CONCLUSION AND RECOMMENDATION}

Due to the economic importance of the Andimeshk-Khorramabad Road, more attention in the maintenance phase of the road is required. In this regard, in order to stabilize the unstable slopes, financial resources should be allocated for the understanding of the geological conditions and the development of the slopes, and soil mechanics and rock mechanics tests should be carried out at a later stage for stability analysis of the slopes (Jones et al., 1997). In the mentioned road, the use of rocket bolts and wire mesh is recommended in order to control the unstable rock slopes. In addition, mostly horizontal and trench drains and Gabion walls should be designed and implemented to stabilize the taluses. In the village of Pol Tang, changing the road direction seems a fundamental solution to solve the problem. [5] 


\section{REFERENCES}

[1] Ghobadi, M., (1997), "Importance of the Geology and Geotechnichs in Evaluation of the Slope Stability in Illawarra, Australia", Second Seminar on Landslides and their damages, Tehran.

[2] Ghobadi, M.H.; 1993-"Landslide in Coalcliff area of the northern Illawarra", Inter. Conf.Env.Manage. Geo.Water and Eng.Aspects. Wollongong, Australia, (Poster paper).

[3] Ghobadi, M.H.; 1994-“ Geology and Slope stability in the northern Illawarra, NSW Australia, $7^{\text {th }}$ Inter. Cong. Asso.Eng.Geology, 1307-1314,Balkema, Rotterdam.

[4] Jonse, B., Chowdhury, R. and Ghobadi, M.H.; 1997-"geological and Environmental factors of slope stability- a case study”, Inter. Symp.Eng. And Environment. Athenes, Greece, in press.

[5] Ghobadi M.H, 1996. Instability of slopes during maintenance phase of the linear structures. Geological society of IRAN.

[6] Aviroop Dutt-Mazumder, Adam C. King, Karl. M. Newell,2019. Recurrence dynamics reveals differential control strategies to maintain balance on sloped surfaces. Gait \& Posture, Volume 69, March 2019, Pages 169-175.

[7] N.Kugler P, Scott Kelso J.A., Turvey M.T., 1980. 1 On the Concept of Coordinative Structures as Dissipative Structures: I. Theoretical Lines of Convergence. Advances in Psychology. Volume 1, 1980, Pages 3-47. https://doi.org/10.1016/S0166-4115(08)61936-6.

[8] Rahul Soangra, Hema Bhatt, Ehsan Rashedi, 2018. Effects of load carriage and surface inclination on linear and non-linear postural variability Safety Science, Volume 110, Part A, December 2018, Pages 427-437. https://doi.org/10.1016/j.ssci.2018.03.019.

[9] Pedro J. Martínez-Ferrer, Ling Qian, Zhihua Ma, Derek M. Causon, Clive G. Mingham, 2018. An efficient finite-volume method to study the interaction of two-phase fluid flows with elastic structures. Journal of Fluids and Structures, Volume 83, November 2018, Pages 54-71. https://doi.org/10.1016/j.jfluidstructs. 2018.08.019.

[10] G. Paliaga, F. Faccini, F. Luino, L. Turconi, P. Bobrowsky, 2019. Geomorphic processes and risk related to a large landslide dam in a highly urbanized Mediterranean catchment (Genova, Italy). Geomorphology, Volume 327, 15 February 2019, Pages 48-61. https://doi.org/10.1016/j.geomorph. 2018.10.020.

[11] Guillermo Tardío, Slobodan B. Mickovski, 2016. Implementation of eco-engineering design into existing slope stability design practices. Ecological Engineering, Volume 92, July 2016, Pages 138-147. https://doi.org/10.1016/j.ecoleng.2016.03.036.

[12] E.Hansen B, 1992. Testing for parameter instability in linear models. Journal of Policy Modeling. Volume 14, Issue 4, August 1992, Pages 517-533. https://doi.org/10.1016/0161-8938(92)90019-9.

[13] Lauren N. Schaefer, Federico Di Traglia, et al. 2019. Monitoring volcano slope instability with Synthetic Aperture Radar: A review and new data from Pacaya (Guatemala) and Stromboli (Italy) volcanoes. EarthScience Reviews, In press, accepted manuscript, Available online 15 March 2019.

[14] William Barham, Scott Bachman, Ian Grooms, 2018. Some effects of horizontal discretization on linear baroclinic and symmetric instabilities. Ocean Modeling, Volume 125, May 2018, Pages 106-116.

[15] Ghosh S, Gunther A, et al.2017. Rock slope instability assessment using spatially distributed structural orientation data in Darjeeling Himalaya (India). Wiley Online Library. Earth Surface Processes and Landforms. Volume 35, Issue 15. December 2010. Pages 1773-1792.

[16] Goodman L.E., Brown C.B. 1963. Dead Load Stresses and the Instability of Slopes. Civil Engineering Database. American Society Of Civil Engineers. Asce Library. Journal of the Soil Mechanics and Foundations Division, 1963, Vol. 89, Issue 3, Pg. 103-136.

[17] Pantelidis L, 2011. A critical review of highway slope instability risk assessment systems. Bulletin of Engineering Geology and the Environment. August 2011, Volume 70, Issue 3, pp 395-400.

[18] Miranda E, ASCE M, D.Akkar S, 2003. Dynamic Instability of Simple Structural Systems. Journal of Structural Engineering / Volume 129 Issue 12 - December.

[19] J. Phys. France, 1988. Localized structures generated by subcritical instabilities. Volume 49, Numéro 11, novembre 1988. DOI: 10.1051/jphys: 0198800490110182900.

[20] Sophie Gschwind, Simon Loew, Andrea Wolter, 2019. Multi-stage structural and kinematic analysis of a retrogressive rock slope instability complex (Preonzo, Switzerland). Engineering Geology, Volume 252, 26 March 2019, Pages 27-42.

[21] Jaboyedoff M, Couture R, Locat P, 2009. Structural analysis of Turtle Mountain (Alberta) using digital elevation model: Toward a progressive failure. Geomorphology. Volume 103, Issue 1, 1 January 2009, Pages 5-16. https://doi.org/10.1016/j.geomorph.2008.04.012. 
[22] Lauren N. Schaefer, Federico Di Traglia, et al. 2019. Monitoring volcano slope instability with Synthetic Aperture Radar: A review and new data from Pacaya (Guatemala) and Stromboli (Italy) volcanoes. EarthScience Reviews, Volume 192, May 2019, Pages 236-257.

[23] Federico Di Traglia, Teresa Nolesini, et al. 2018. Tracking morphological changes and slope instability using spaceborne and ground-based SAR data. Geomorphology, Volume 300, 1 January 2018, Pages 95-112. https://doi.org/10.1016/ j.geomorph.2017.10.023.

[24] Bohme M, Oppikofer T, et al, 2015. Analyses of past and present rock slope instabilities in a fjord valley: Implications for hazard estimations. Geomorphology. Volume 248, 1 November 2015, Pages 464-474. https://doi.org/10.1016/j.geomorph.2015.06.045.

[25] Agliardi F, Crosta G.B, et al, 2013. Structurally-controlled instability, damage and slope failure in a porphyry rock mass. Tectonophysics. Volume 605, 11 October 2013, Pages 34-47. https://doi.org/10.1016/j.tecto.2013.05.033

[26] Basahel H, Mitri H, 2017. Journal of Rock Mechanics and Geotechnical Engineering. Volume 9, Issue 6, December 2017, Pages 993-1009 https://doi.org/10.1016/j.jrmge.2017.07.007

[27] Aksoy, 2008, C. AksoyReview of rock mass rating classification: historical developments, applications, and restrictions. Journal of Mining Science, 44 (1) (2008), pp. 51-63

[28] Anbalagan, 1992. R. AnbalaganLandslide hazard evaluation and zonation mapping in mountainous terrain. Engineering Geology, 32 (4) (1992), p. 269-277

[29] Anbalagan et al., 1992, R. Anbalagan, S. Sharma, T.K. RaghuvanshiRock mass stability evaluation using modified SMR approach, proceedings of the 6th National Symposium on Rock Mechanics (1992), pp. 258-268.

[30] Bieniawski, 1973. Z.T. Bieniawski Engineering classification of jointed rock masses. Civil Engineer in South Africa, 15 (12) (1973), pp. 335-343

[31] Bieniawski, 1976. Z.T. BieniawskiExploration for rock engineering: roceedings of the Symposium on exploration for rock engineering

[32] A.A. Balkema, Cape Town, South Africa (1976).

[33] Bieniawski, 1979. Z.T. Bieniawski The geomechanics classification in rock engineering applications. Proceedings of the 4th ISRM Congress, International Society for Rock Mechanics (1979).

[34] Bieniawski, 1989. Z.T. Bieniawski Engineering rock mass classifications: a complete manual for engineers and geologists in mining, civil, and petroleum engineering

[35] Bieniawski, 1993. Z.T. Bieniawski Classification of rock masses for engineering: the RMR system and future trends. Rock Testing and Site Characterization (1993), pp. 553-573

[36] Chen, 1995. Z. ChenRecent developments in slope stability analysis

[37] T. Fujii (Ed.), Proceedings of the 8th International Congress of Rock Mechanic, vol. 3 (1995), pp. 10411048

[38] Coggan et al., 1998. J.S. Coggan, D. Stead, J.M. Eyre Evaluation of techniques for quarry slope stability assessment. Transactions of the Institutions of Mining and Metallurgy, Section B: Applied Earth Science (1998), p. 107

[39] Duran and Douglas, 2000. A. Duran, K. Douglas Experience with empirical rock slope design. proceedings of ISRM International Symposium (2000)

[40] Goodman and Bray, 1976. R.E. Goodman, J.W. Bray Toppling of rock slopes

[41] Rock engineering for foundations \& slopes (1976).

[42] Hack et al., 2003. R. Hack, D. Price, N. RengersA new approach to rock slope stability-a probability classification (SSPC). Bulletin of Engineering Geology and the Environment, 62 (2) (2003), pp. 167-184

[43] Hoek and Bray, 1981. E. Hoek, J. Bray Rock slope engineering

[44] (Revised 3rd ed), the Institution of Mining and Metallurgy, London (1981)

[45] Hoek and Marinos, 2000. E. Hoek, P. MarinosPredicting tunnel squeezing problems in weak heterogeneous rock masses. Tunnels and Tunneling International, 32 (11) (2000), pp. 45-51

[46] Hoek, 2007. E. HoekRock mass properties. Practical rock engineering (2007)

[47] www.rocscience.com/learning/hoek-s-corner.

[48] Pachauri and Pant, 1992. A.K. Pachauri, M. Pant Landslide hazard mapping based on geological attributes. Engineering Geology, 32 (1-2) (1992), pp. 81-100.

[49] Pantelidis, 2009, L. PantelidisRock slope stability assessment through rock mass classification systems. International Journal of Rock Mechanics and Mining Sciences, 46 (2) (2009), pp. 315-325

[50] Pantelidis, 2010. L. PantelidisAn alternative rock mass classification system for rock slopes. Bulletin of Engineering Geology and the Environment, 69 (1) (2010), pp. 29-39 
[51] Price and Cosgrove, 1990. N.J. Price, J.W. CosgroveAnalysis of geological structures. Cambridge University Press, Cambridge, England (1990)

[52] Rocscience Inc, 2014. Rocscience IncDip v. 6.0 - graphical and statistical analysis of orientation data. Toronto, Canada

[53] Romana, 1985. Roman anew adjustment ratings for application of Bieniawski classification to slopes. In: proceedings of international symposium on the role of rock mechanics. ISRM, Zacatecas (1985), pp. 49-53

[54] Sen and Sadagah, 2003. Z. Sen, B.H. SadagahModified rock mass classification system by continuous rating. Engineering Geology, 67 (3-4) (2003), pp. 269-280

[55] Tomás et al., 2007. R. Tomás, J. Delgado, J.B. SerónModification of slope mass rating (SMR) by continuous functions. International Journal of Rock Mechanics and Mining Sciences, 44 (2007), pp. 10621069

[56] Tomás et al., 2012. R. Tomás, A. Cuenca, M. Cano, J. Garcßa-BarbraA graphical approach for slope mass rating (SMR). Engineering Geology, 124 (4) (2012), pp. 67-76

[57] Wyllie and Mah, 2004. D.C. Wyllie, C. MahRock slope engineering. (4th ed), CRC Press (2004)

Citation: Moein Zargar, et.al. "Unpredictability of Gradients during Preservation Phase of the Linear Constructions", International Journal of Constructive Research in Civil Engineering, 5(2), pp. 1-8. DOI: http://dx. doi.org/10.20431/2454-8693.0502001

Copyright: (C) 2019 Authors, This is an open-access article distributed under the terms of the Creative Commons Attribution License, which permits unrestricted use, distribution, and reproduction in any medium, provided the original author and source are credited. 